\title{
Keterampilan Pemecahan Masalah Matematika di Era Revolusi Industri 4.0 Siswa SD
}

\author{
Maifit Hendriani ${ }^{1}$, Silfi Melindawati ${ }^{2}$, Afri Mardicko ${ }^{3}$ \\ ${ }^{1,2}$ PGSD STKIP Adzkia, Jl. Taratak Paneh No 7 Kuranji Padang, Sumatera Barat, Indonesia \\ ${ }^{3}$ PGSD Universitas Muhammadiyah Pringsewu, Jl. KH. Ahmad Dahlan No.112, Pringsewu Barat., Kec. Pringsewu, \\ Kabupaten Pringsewu, Lampung, \\ maifithendriani92@gmail.com
}

\begin{abstract}
This research is motivated by the importance of problem's solving skills in the era of the industrial revolution 4.0, so it is necessary to analyze the mathematics problem solving skills of elementary school students. The urgency of this research is as a foundation for teachers in planning, implementing, and evaluating the learning process, as well as a foundation for policy makers in making policies related to education. This research method used descriptive qualitative with a population of all fifth's grade students of SD in the IV Nagari District, Sijunjung Regency which consists of 7 SD. The research subjects were 91 students. The research instrument used was in the form of 7 problem solving skills test questions in the form of essays that had been tested for validity, difference power, difficulty level and reliability. The results of the study concluded that students' problem-solving skills were hampered by the third indicator, namely solving problems with a percentage of 34\% (31 students), which was caused by the students' weak ability in carrying out number operations, using formulas and the students' weak ability to link between elements. known elements in the problem.
\end{abstract}

Keywords: Problem Solving Skills, Mathematics, Elementary School

\begin{abstract}
Abstrak
Penelitian ini dilatar belakangi pentingnya keterampilan pemecahan masalah di era revolusi industry 4.0, sehingga keterampilan pemecahan masalah matematika siswa SD perlu untuk dianalisis. Urgensi penelitian ini yaitu sebagai landasan untuk proses pembelajaran dalam hal merencanakan, melaksanakan, dan mengevaluasi, juga landasan bagi pembuat kebijakan dalam membuat kebijakan terkait pendidikan. Metode deskripstif kualitatif digunakan dalam studi ini. Populasi penelitiannya seluruh anak kelas V SD di Kecamatan IV Nagari Kabupaten Sijunjung yang terdiri dari 7 sekolah. Subjek penelitian berjumlah 91 siswa. Instrument penelitian yang digunakan berupa tes keterampilan pemecahan masalah berbentuk essay yang valid, teruji daya beda, tingkat kesukaran sedang dan reliabilitas sebanyak 7 butir. Hasil analisis yaitu, keterampilan siswa ketika memecahkan masalah terhambat pada indikator ke tiga yaitu menyelesaikan masalah dengan persentase 34\% (31 siswa), yang disebabkan oleh lemahnya kemampuan siswa dalam pengerjaan operasi bilangan, penggunaan rumus dan lemahnya kemampuan siswa dalam mengaitkan antar unsur yang diketahui dalam soal.

Kata Kunci: Keterampilan Pemecahan Masalah, Matematika, SD
\end{abstract}

Copyright (c) 2021 Maifit Hendriani, Silfi Melindawati, Afri Mardicko

$\triangle$ Corresponding author: Maifit Hendriani

Email Address: maifithendriani92@gmail.com (J1. Taratak Paneh No 7 Kuranji Padang)

Received 22 January 2021, Accepted 07 March 2021, Published 09 April 2021

\section{PENDAHULUAN}

Era revolusi indutri 4.0 mengubah kompetensi Sumber Daya Manusia (SDM) yang di butuhkan di dunia pekerjaan. Keterampilan pemecahan masalah merupakan kompetensi utama yang dibutuhkan di era ini. Menurut NACE (National Association of Colleges and Employers) berdasarkan survey yang dilakukan (Dwi \& Wibowo, 2019), dengan bobot penilaian 82, 9 \% pencari kerja di revolusi industri 4.0 harus menunjukkan kemampuan mereka dalam memecahkan masalah. Terampil memecahkan masalah menjadikan orang produktif dan berpacu untuk kebutuhan hidupnya, serta bisa memahami isuisu kompleks terkait masyarakat global. (Kurniawan, 2015). 
Keterampilan pemecahan masalah adalah kemampuan melakukan penalaran, membuat pilihan, memahami interkoneksi, menyusun, mengungkapkan, dan menganalisa untuk memecahkan masalah yang dihadapi (Parwati, 2019). Kurikulum 2013 revisi 2018 menjadikan pemecahan masalah dalam pembelajaran matematika sebagai alat dan tujuan utama dari pembelajaran matematika (Kementerian et al., 2014). Sehingga, siswa mampu menggunakan konsep matematika untuk memecahkan masalah dikehidupannya sehari-hari. Untuk mampu memecahkan masalah, dibutuhkan pengetahuan dasar dan keterampilan dasar yang meliputi masalah dianalisis, antar konsep yang relevan dalam masalah dikaitkan, tepat dalam memilih alternatif penyelesaian masalah (Anesa Surya, 2019). Siswa bisa dikatakan terampil dalam memecahkan masalah jika memenuhi indikasi pemecahan masalah diantaranya, masalah dipahami siswa, rencana pemecahan masalah disusun siswa dan masalah dipecahkan.

Penelitian yang berkaitan dengan menganalisis keterampilan pemecahan masalah matematika telah pernah dilakukan, diantaranya, hasil penelitian (Andayani \& Lathifah, 2019) di tingkat Sekolah Menengah Pertama (SMP), dari hasil penelitian ditemukan bahwa siswa kesulitan dalam memahami soal aritmatika sosial, dan hanya Sebagian siswa yang memenuhi indikator dalam permodelan matematika, pemilihan strategi penyelesaiaan, pemecahan masalah, dan pemeriksaan ulang hasil jawaban. Lebih lanjut peneliti menyarankan untuk membiasakan siswa memecahkan soal tidak rutin sehingga meningkat kemampuan siswa dalam memecahkan masalah.

Hasil analisis (Suraji et al., 2017), di tingkat SMP menunjukkan bahwa, siswa cenderung mengalami kesulitan dalam hal perhitungan walaupun sudah memahami maksud dari soal. Selanjutnya, hasil penelitian (Fitria et al., 2018) di tingkat SMP, keterampilan siswa dalam memecahkan masalah tergolong rendah, terutama pada tahap memahami soal dan pengecekkan ulang proses serta jawaban yang ditemukan dari penyelesaian soal. Dari hasil analisis ini peneliti menyarankan kepada guru untuk membiasakan siswa menghadapi soal-soal non rutin, agar terlatih dalam menyelesaikan masalah.

Studi ini berbeda dengan yang sudah ada, yaitu menganalisis keterampilan pemecahan masalah matematika siswa ditingkat SD. Hal ini penting diteliti karena ditingkat pendidikan yang lebih tinggi keterampilan pemecahan masalah siswa tergantung kepada pengalaman belajar siswa di tingkat SD (Suhartono, 2018). Selain itu, melatih keterampilan pemecahan masalah sejak dini merupakan langkah untuk mewujudkan tujuan belajar matematika didukung oleh Kompetensi Dasar (KD) di dalam kurikulum 2013.

Berdasarkan penjelasan sebelumnya, tujuan studi ini untuk menganalisis keterampilan pemecahan masalah matematika anak kelas $\mathrm{V}$ di SD, sebagai dasar untuk guru maupun pembuat kebijakan dalam merencanakan dan mengembangkan pembelajaran inovatif untuk pengembangan keterampilan pemecahan masalah matematika. 


\section{METODE}

Studi ini menggunakan metode analisis deskriptif. Penelitian dengan populasi semua siswa kelas 5 SD yang berjumlah 146 siswa di kecamatan IV Nagari Kabupaten Sijunjung. Simple random sampling teknik digunakan untuk proses penarikan sampel sehingga diperoleh 91 siswa. Instrument penelitian yaitu 7 soal yang teruji tingkat validitas, daya pembeda, indeks kesukaran serta reliabilitas. Langkah-langkah penelitian adalah persiapan, pelaksanaan dan akhir. Langkah persiapaan, melakukan pra riset ke siswa SD, menyiapkan instrument penelitian yaitu tes soal matematika kemampuan pemecahan masalah, merevisi soal keterampilan pemecahan masalah sesuai hasil validasi dengan validator. Langkah pelaksanaan; pemberian soal kepada subjek, menganalisis jawaban subjek penelitian berdasarkan pedoman penskoran. Tahap teakhir menganalisis jawaban subjek, menguraikan hasil analasis serta menjawab rumusan masalah.

\section{HASIL DAN DISKUSI}

Analisis dilakukan di kelas V SD Se kecamatan Empat Nagari, Kabupaten Sijunjung dengan jumlah siswa 91 siswa dari 6 sekolah. Instrumen keterampilan pemecahan masalah diberikan disusun berdasarkan tiga indikator diantaranya, "1) Mengidentifikasi unsur-unsur yang diketahui, ditanyakan dan kecukupan unsur-unsur yang diperlukan, 2) Menentukan strategi yang tepat dalam menyelesaikan permasalahan, 3) Menyelesaikan masalah. Penilaian keterampilan pemecahan masalah dihitung dengan cara penskoran menggunakan rubrik. Sebagai berikut:

Tabel 1. Rubrik Penilaian Tes Keterampilan Pemecahan Masalah Matematika

\begin{tabular}{|c|c|c|c|}
\hline Skor & $\begin{array}{c}\text { Mengidentifikasi } \\
\text { diketahui, ditanyakan } \\
\text { dan kecukupan unsur- } \\
\text { unsur diperlukan }\end{array}$ & $\begin{array}{l}\text { Menentukan strategi } \\
\text { tepat menyelesaikan } \\
\text { permasalahan }\end{array}$ & Menyelesaikan soal \\
\hline 0 & Tidak terdapat jawaban & Tidal & $\begin{array}{l}\text { Tidak } \\
\text { jawaban }\end{array}$ \\
\hline 1 & $\begin{array}{l}\text { Jawaban sedikit, namun } \\
\text { belum tepat untuk } \\
\text { mengidentifikasi diketahui, } \\
\text { ditanyakan, dan kecukupan } \\
\text { unsur yang diperlukan }\end{array}$ & $\begin{array}{lr}\text { Ada sedikit jawaban, } \\
\text { tetapi belum tepat dalam } \\
\text { menentukan strategi } \\
\text { menyelesaikan masalah } \\
\text { yang tepat. }\end{array}$ & $\begin{array}{l}\text { Ada sedikit jawaban, } \\
\text { tetapi tepat untuk } \\
\text { menyelesaikan soal } \\
\text { yang muncul }\end{array}$ \\
\hline 2 & $\begin{array}{l}\text { Ada jawaban, namun } \\
\text { terdapat sedikit kesalahan } \\
\text { dalam mengidentifikasi } \\
\text { diketahui, ditanyakan, dan } \\
\text { kecukupan unsur yang } \\
\text { diperlukan. }\end{array}$ & $\begin{array}{l}\text { Ada jawaban, tetapi } \\
\text { terdapat sedikit kesalahan } \\
\text { dalam menentukan } \\
\text { strategi menyelesaikan } \\
\text { masalah yang tepat. }\end{array}$ & $\begin{array}{lr}\text { Ada jawaban, } & \text { namun } \\
\text { terdapat } & \text { sedikit } \\
\text { kesalahan } & \text { dalam } \\
\text { menyelesaikan } & \text { soal } \\
\text { yang muncul. } & \end{array}$ \\
\hline 3 & $\begin{array}{l}\text { Jawaban benar dan tepat } \\
\text { dalam mengidentifikasi } \\
\text { diketahui, ditanyakan, dan } \\
\text { kecukupan unsur yang } \\
\text { diperlukan. }\end{array}$ & $\begin{array}{l}\text { Jawaban benar dan tepat } \\
\text { dalam menentukan } \\
\text { strategi menyelesaikan } \\
\text { masalah yang tepat. }\end{array}$ & $\begin{array}{lr}\text { Jawaban benar } & \text { dan } \\
\text { tepat } & \text { dalam } \\
\text { menyelesaikan } & \text { soal } \\
\text { yang muncul } & \end{array}$ \\
\hline & Nilai Maks. 3 & Nilai Maks. 3 & Nilai Maks. 3 \\
\hline
\end{tabular}

Sumber : Diadaptasi dari Fauzan (2012:35) 
Instrumen diuji terlebih dahulu sebelum digunakan untuk penelitian. Ujicoba instrumen dilakukan terhadap populasi yang memiliki karakteristik yang sama, tetapi diluar sampel yang ditentukan, dalam penelitian ini sampel uji coba adalah siswa SD Negeri 13 Palangki di Kecamatan IV Nagari, Kabupaten Sijunjung.

Hasil uji validitas instrumen menunjukkan bahwa semua butir soal dinyatakan valid sebanyak 10 butir soal yaitu nomor 1, 2, 3, 4, 5, 6, 7, 8 9, dan 10. Dari hasil analisis tingkat kesukaran tes keterampilan pemecahan masalah matematika, maka soal nomor 1, 3, 5, 6, 7, 8, 9 dan 10 termasuk kriteria soal sedang, dan soal nomor 2 dan 4 termasuk kriteria soal sukar. Dari hasil analisis diperoleh daya pembeda tes keterampilan pemecahan masalah matematika, maka soal nomor 2, 3 dan 4 termasuk kepada soal dengan kriteria jelek, soal nomor 1, 5, 7 dan 10 termasuk kepada soal dengan kriteria cukup, soal nomor 6, 8 dan 9 termasuk kepada soal dengan kriteria baik. Dan hasil perhitungan reliabilitas uji coba soal tes keterampilan pemecahan masalah matematika diperoleh $r_{11}=0,71$, berarti soal berada pada kriteria reliabilitas tinggi dan ini menunjukkan soal tes dapat dipercaya. Berdasarkan hasil uji coba instrumen maka, soal yang bisa digunakan untuk penelitian adalah 7 butir soal. Berdasarkan tes keterampilan pemecahan masalah yang berikan kepada anak, dihasilkan data berikut.

\section{Indikator 1: Mengidentifikasi mengidentifikasi diketahui, ditanyakan, dan kecukupan unsur yang diperlukan}

Hasil distribusi skor keterampilan pemecahan masalah matematika indikator mengidentifikasi diketahui, ditanyakan, dan kecukupan unsur yang diperlukan ditampilkan dalam bentuk diagram lingkaran berikut:

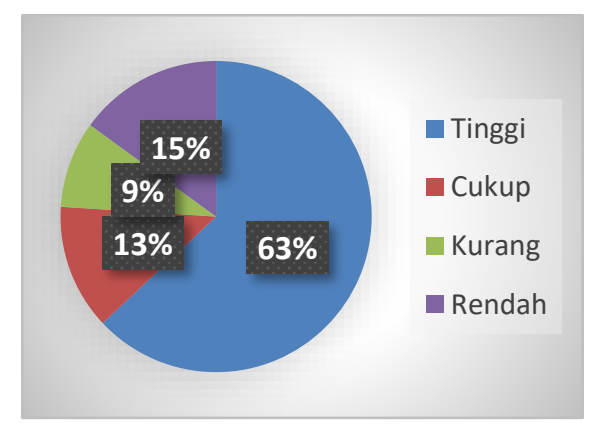

Gambar 1. Distribusi skor variabel keterampilan Pemecahan Masalah Matematika indikator mengidentifikasi diketahui, ditanyakan, dan kecukupan unsur yang diperlukan

Berdasarkan gambar 1 menunjukkan bahwa keterampilan mengidentifikasi diketahui, ditanyakan, dan kecukupan unsur yang diperlukan dalam kategori tinggi sebanyak 57 siswa (63\%), dengan arti sebesar 63\% siswa telah menguasai keterampilan pemecahan masalah matematika untuk indikator mengidentifikasi unsur-unsur yang diketahui, ditanya, dan kecukupan unsur-unsur yang diperlukan dengan kategori tinggi. Kemudian, untuk kategori cukup sebanyak 12 siswa (13\%), dengan arti sebesar $13 \%$ siswa menguasai keterampilan pemecahan masalah matematika untuk indikator kemampuan mengidentifikasi diketahui, ditanyakan, dan kecukupan unsur yang diperlukan dengan kategori cukup. Untuk kategori kurang sebanyak 8 siswa (9\%), dengan arti 9\% siswa menguasai 
keterampilan pemecahan masalah matematika untuk indikator mengidentifikasi diketahui, ditanyakan, dan kecukupan unsur yang diperlukan dengan kategori kurang, kemudian kategori rendah sebanyak 14 siswa (15\%), dengan arti $15 \%$ siswa menguasai keterampilan pemecahan masalah matematika untuk indikator mengidentifikasi diketahui, ditanyakan, dan kecukupan unsur yang diperlukan dengan klasifikasi rendah. Disimpulkan bahwa anak kelas 5 SDN Kecamatan IV Nagari Kabupaten Sijunjung cenderung tinggi dengan rata-rata 14,69 pada keterampilan pemecahan masalah matematika indikator mengidentifikasi diketahui, ditanyakan, dan kecukupan unsur yang diperlukan.

\section{Indikator 2: Menentukan Strategi Yang Tepat Dalam Menyelesaikan Permasalahan}

Hasil distribusi skor keterampilan pemecahan masalah matematika indikator Memilih berbagai pendekatan atau strategi untuk memecahkan masalah ditampilkan dalam bentuk diagram lingkaran berikut:

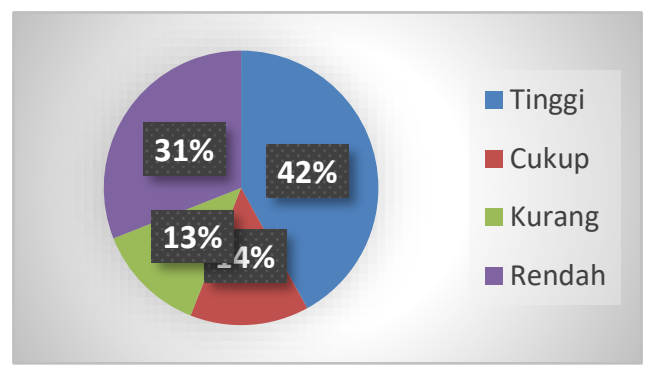

Gambar 2. Distribusi skor variabel keterampilan Pemecahan Masalah Matematika indikator menentukan strategi menyelesaikan masalah yang tepat

Berdasarkan diagram di atas menggambarkan keterampilan siswa dalam Memilih berbagai pendekatan atau strategi untuk memecahkan masalah dalam kategori tinggi sebanyak 38 siswa (42\%), dengan arti sebesar $42 \%$ siswa telah menguasai keterampilan pemecahan masalah matematika untuk indikator menentukan strategi menyelesaikan masalah yang tepat. Kemudian, untuk kategori cukup sebanyak 13 siswa (14\%), dengan arti sebesar 14\% siswa menguasai keterampilan pemecahan masalah matematika untuk indikator menentukan strategi menyelesaikan masalah yang tepat dengan kategori cukup. Untuk kategori kurang sebanyak 12 siswa (13\%), dengan arti 13\% siswa menguasai keterampilan pemecahan masalah matematika untuk indikator menentukan Strategi yang tepat dalam menyelesaikan permasalahan dengan kategori kurang, kemudian kategori rendah sebanyak 28 siswa (31\%), dengan arti $31 \%$ siswa menguasai keterampilan pemecahan masalah matematika untuk indikator menentukan Strategi tepat dalam menyelesaikan permasalahan dengan klasifikasi rendah. Disimpulkan bahwa siswa kelas V SDN Kecamatan Empat Nagari Kabupaten Sijunjung cenderung tinggi dengan rata-rata 12,45 pada keterampilan pemecahan masalah matematika indikator menentukan strategi menyelesaikan masalah yang tepat.

\section{Indikator 3: Menyelesaikan Soal/Permasalahan Yang Muncul}

Hasil distribusi skor keterampilan pemecahan masalah matematika indikator Menyelesaikan soal/Permasalahan yang muncul ditampilkan dalam bentuk diagram lingkaran berikut: 


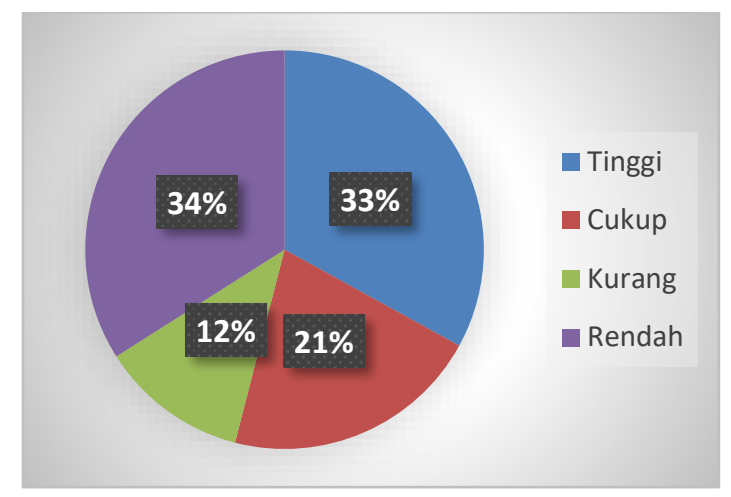

Gambar 3. Distribusi skor variabel keterampilan Pemecahan Masalah Matematika indikator Menyelesaikan soal/Permasalahan yang muncul

Berdasarkan Gambar 3 menunjukkan bahwa keterampilan siswa dalam Menyelesaikan soal/Permasalahan yang muncul. dalam kategori tinggi sebanyak 30 siswa (33\%), dengan arti sebesar $33 \%$ siswa telah menguasai keterampilan pemecahan masalah matematika pada indikator Menyelesaikan soal/Permasalahan yang muncul. Kemudian, untuk kategori cukup sebanyak 19 siswa (21\%), dengan arti sebesar $21 \%$ siswa menguasai keterampilan pemecahan masalah matematika pada indikator Menyelesaikan soal/Permasalahan yang muncul. Untuk kategori kurang sebanyak 11 siswa (12\%), dengan arti $12 \%$ siswa menguasai keterampilan pemecahan masalah matematika pada indikator Menyelesaikan soal/Permasalahan yang muncul, kemudian kategori rendah sebanyak 31 siswa (34\%), dengan arti $34 \%$ siswa menguasai keterampilan pemecahan masalah matematika pada indikator Menyelesaikan soal/Permasalahan yang muncul. Disimpulkan bahwa siswa kelas V SDN Kecamatan Empat Nagari Kabupaten Sijunjung cenderung rendah dengan rata-rata 12,56 pada keterampilan pemecahan masalah matematika indikator menyelesaikan soal/permasalahan yang muncul.

Berdasarkan penjelasan di atas, data hasil penelitian menunjukan bahwa keterampilan siswa dalam menyelesaikan masalah terhambat pada indikator ketiga, yakni menyelesaikan masalah. analisis ini senada dengan hasil penelitian (Mariam et al., 2018), dari 20 siswa, keterampilan siswa menyelesaikan masalah pada indikator ketiga hanya $10 \%$. Keterampilan ini dapat ditingkatkan melalui latihan-latihan soal pemecahan masalah. (Simalango et al., 2018), Siswa perlu mendapatkan pengalaman memecahkan soal, sehingga bisa mengembangkan kemampuan siswa dalam memecahkan masalah.

Sejalan dengan hasil penelitian (Bernard et al., 2018), dari total 15 siswa, 27,\% siswa terhambat pada tahap ppenyelesaian masalah indicator ketiga, disebabkan siswa lemah dalam pengerjaan operasi bilangan, sehingga belum mampu mengerjakan atau menuntaskan pemecahan masalah dan siswa tidak mampu mengaplikasikan materi kebentuk lain dengan benda nyata.

Hasil penelitian ini senada dengan laporan Programme for International Student Asessment (PISA), ditahun 2018 dari total 78 negara yang berpartisipasi skor Matematika peserta didik Indonesia ada di peringkat 72. Pada tahun 2015, Indonesia diperingkat 69 dari 79 negara peserta. Berdasarkan hasil analisis siswa Indonesia kesulitan ketika menyelesaikan soal level 5 yang membutuhkan keterampilan 
pemecahan masalah. Dari seluruh peserta yang berasal dari Indonesia hanya $1 \%$ siswa yang mampu menyelesaikannya (OECD, 2018).

Terdapat faktor yang mempengaruhi keterampilan anak dalam memecahkan masalah, menurut (Kudsiyah et al., 2017), dari hasil penelitiannya 8 faktor signifikan yang mempengaruhi keterampilan pemecahan masalah yaitu, kesulitan belajar, kurang penguasaan materi, konteks masalah, pemahaman, kegiatan berfikir panjang, kegiatan belajar sebelumnya, penggunaan rumus, sudut padang terhadap matematika (suka/tidak suka), mood, motivasi, perhatian, rasa malas, respon/tanggapan, keaktifan dan diskusi. Dari 8 penyebab di atas kesulitan belajar merupakan factor yang paling berpengaruh dalam keterampilan pemecahan masalah. Kesulitan belajar adalah rendahnya kemampuan menguasai konsep, kesulitan dalam pengerjaan, lupa rumus dan kekeliruan perhitungan. Ini yang menjadi penyebab rendahnya persentase siswa pada indikator menyelesaikan masalah.

Era revolusi industri 4.0 menginginkan SDM terampil dalam memecahkan masalah. Maka, untuk mengatasi rendahnya keterampilan siswa dalam memcahkan masalah guru harus membiasakan siswa berhadapan dengan soal-soal non rutin. Jack ma (Surani, 2019) mengatakan, Jika pendidikan masih mengesampingkan keterampilan maka SDM yang dihasilkan tidak akan mampu berkompetisi dengan mesin. Inilah yang sedang terjadi direvolusi industry 4.0, pergerakan inovasi teknologi sangat cepat menjadikan kita Sebagian besar berbagi tempat kerja dengan kecerdasan robot buatan.

\section{KESIMPULAN}

Sesuai dengan hasil analisis, maka dapat disimpulkan, keterampilan pemecahan masalah anak kelas lima SD se kecamatan IV Nagari, Kabupaten Sijunjung mengalami hambatan pada indicator ketiga yaitu menyelesaikan masalah sebanyak 31 siswa (34\%). Penyebabnya adalah lemahnya kemampuan siswa dalam pengerjaan operasi bilangan, dan lemahnya kemampuan siswa dalam mengaitkan antar unsur-unsur yang diketahui dalam masalah.

\section{UCAPAN TERIMA KASIH}

Terimakasih kami ucapkan kepada Bapak/Ibu Kepala Sekolah, Guru serta seluruh peserta didik kelas V SD di Kecamatan IV Nagari Kabupaten Sijunjung yang sudah memberikan dukungan, izin, dan turut serta berpartisipasi dalam terlaksananya penelitian ini.

\section{REFERENSI}

Andayani, F., \& Lathifah, A. N. (2019). Analisis Kemampuan Pemecahan Masalah Siswa SMP dalam Menyelesaikan Soal Pada Materi Aritmatika Sosial. Jurnal Cendekia: Jurnal Pendidikan Matematika, 3(1), 1-10. https://doi.org/10.31004/cendekia.v3i1.78

Anesa Surya, M. W. S. I. (2019). Keterampilan Pemecahan Masalah MatematisPada Peserta Didik Kelas

V Sekolah Dasar. Jurnal Pendidikan Dasar, 7(1), 1-6. https://doi.org/10.20961/jpd.v7i1.29300

Bernard, M., Nurmala, N., Mariam, S., \& Rustyani, N. (2018). Analisis Kemampuan Pemecahan 
Keterampilan Pemecahan Masalah Matematika di Era Revolusi Industri 4.0 Siswa SD, Maifit Hendriani, Silfi Melindawati, Afri Mardicko

Masalah Matematis Siswa SMP Kelas IX Pada Materi Bangun Datar. SJME (Supremum Journal of Mathematics Education), 1(1), 77. https://doi.org/10.22460/jpmi.v1i5.p1025-1036

Dwi, U., \& Wibowo, A. (2019). PROPHETIC SOFTSKILLS UNTUK BERSAING DI ERA REVOLUSI INDUSTRI 4 . O PROPHETIC SOFT SKILLS TO COMPETE IN THE ERA OF 4 . 0 th INDUSTRIAL REVOLUTION ( MEA ) yang diberlakukan mulai tahun 2015 , di mana saat ini lembaga pendidikan tinggi mahasiswanya . Dalam K. 21(1), 30-38.

Fitria, N. F. N., Hidayani, N., Hendrian, H., \& Amelia, R. (2018). Analisis Kemampuan Pemecahan Masalah Matematik Siswa SMP dengan Materi Segitiga dan Segiempat. Edumatica, 08(1), 49-57.

Kementerian, Pendidikan, \& Kebudayaan. (2014). Permendikbud no.36 tahun 2014. Permendikbud,112.

Kudsiyah, S. M., Novarina, E., \& Lukman, H. suryani. (2017). Faktor-Faktor Yang Mempengaruhi Kemampuan Pemecahan Masalah Matematika Kelas X Di Sma Negeri 2 Kota Sukabumi. Education: Prodi Pendidikan Matematika FKIP Universitas Muhammadiyah Sukabumi, 110-117.

Kurniawan, H. (2015). Analisis Keterampilan Pemecahan Masalah Pada Pembelajaran Matematika. Jurnal Pendidikan Surya Edukasi, 1(1), 121692.

Mariam, S., Rohaeti, E. E., \& Sariningsih, R. (2018). Analisis Kemampuan Pemecahan Masalah Matematis Siswa Madrasah Aliyah pada Materi Pola Bilangan. Journal on Education, 1(2), 156162.

OECD. (2018). What 15-year-old students in Indonesia know and can do. Programme for International Student Assessment (PISA) Result from PISA 2018, 1-10. http://www.oecd.org/pisa/ Data

Parwati, ni nyoman. (2019). Prosiding Senama PGRI Volume 1 Tahun 2019. Adaptasi Pembelajaran Matematika Di Era Revolusi Industri 4.0, 1(87). https://doi.org/10.5281/zenodo.3445646

Simalango, maria mareta, Darmawijoyo, \& Aisyah, N. (2018). ANALISIS KESULITAN SISWA DALAM MENYELESAIKAN SOAL-SOAI PISA TAHUN 2012 LEVEL 4, 5, DAN 6 DI SMP N 1 INDRALAYA. Jurnal Pendidikan Matematika, 12(1), 43-58. https://doi.org/10.22342/jpm.11.2.2143.

Suhartono, S. (2018). Mengajarkan Pemecahan Masalah Matematika di Sekolah Dasar. Matematika Dan Pembelajaran, 6(2), 215. https://doi.org/10.33477/mp.v6i2.671

Suraji, Maimunah, \& Saragih, S. (2017). Analisis Kemampuan Pemahaman Konsep Matematis dan Kemampuan Pemecahan Masalah Matematis Siswa SMP pada Materi Sistem Persamaan Linear Dua Variabel (SPLDV). Suska Journal of Mathematics Education, 3(2), 130. https://doi.org/10.24014/sjme.v3i2.3897

Surani, D. (2019). Studi Literatur: Peran Teknolog Pendidikan Dalam Pendidikan 4.0. Prosiding Seminar Nasional Pendidikan FKIP, 2(1), 456-469. 